\title{
The Impact of Foreign Direct Investment On Economic Growth
}

\section{In Nigeria}

\author{
A.A. Awe (Ph.d)* \\ Department of Economics Ekiti State University Ado-Ekiti, Ekiti State Nigeria \\ *aweabelariyo@yahoo.com
}

\begin{abstract}
This study examines the impact of foreign direct investment on economic growth in Nigeria during the period 1976 - 2006, using the two-stage least squares (2SLS) method of simultaneous equation model. The findings of the study revealed a negative relationship between economic growth proxied by Gross Domestic Product (GDP) and Foreign Direct Investment (FDI) as a result of insufficient FDI flow into the Nigerian economy. It is therefore, recommended that Nigeria should encourage domestic investment to accelerate growth rather than relying on FDI as a primer mover of the economy and develop a code of conduct on FDI to curb the restrictive business practice of multinationals and limit their repatriation of profits from Nigeria.
\end{abstract}

Keywords: Foreign Direct Investment, Economic Growth, Nigerian Economy.

\section{Introduction}

There exists a large theoretical and empirical literature about the impact of Multinational Corporations (MNCs) and foreign direct investment (FDI) economic growth in developing countries. In the 1960s and 1970s, MNCs were considered to be responsible for persisting and widening inequalities between industrialized and less developed countries. However, in recent years, a much more optimistic view of positive thought on the role of multinational corporations (MNCs) and foreign direct investment has prevailed. The change in thought reflects both important economic events and theoretical developments. On one side, the debt crisis which started in 1982 left many developing countries with very little access to foreign financial resources. This made foreign direct investment (FDI) which is essentially equity and not debt, an attracting form of foreign capital.

In addition, the emergence of "endogenous growth" theories emphasized the importance of human capital accumulation and technological externalities in development processes. In this respect, Multinational Corporations (MNCs) which relies on the most advanced production and organization methods, are seen as powerful vehicles of technology transfer to less developed economies like Nigeria. In this regard, the classical paper of Findlay (1978) represents a first formal example of the potential link between foreign direct investment and technology transfer while the models of the "new growth theory" provides a very useful tool to analyze how the introduction of new inputs and technologies influences the production function of a foreign economy and how externalities affect the research efforts of the economic agents and the diffusion of knowledge. Hence, endogenous growth theory constitutes the predominant theoretical framework within which recent research studies the impact of foreign direct investment (FDI) on growth (Borensztein 1998 and Martin and Ottaviano 1999).

The agreement between the academic world and international organizations that MNCs play positive roles in the development and growth process permits many developing countries to design policies that attracted foreign investment from industrialized countries. This notwithstanding, De Mello (1997) in his survey about (FDI) and growth in developing countries noted that "whether foreign direct investment (FDI) can be deemed to be a catalyst for output growth, capital accumulation and technological progress is less controversial hypothesis in theory than in practice". 
The available empirical literature on the impact of foreign direct investment (FDI) on growth provides contrasting results not only about he existence of a significant link between foreign direct investment and growth rates of the recipient country, but also about the signs of such relationships. For instance, in Bornschier (1978) and Dutt (1997), growth rates are negatively related to foreign capital stocks but in Dutt, (1996) the same relationship turns out to be positive. Blomstorm (1992) find a significant positive impact of FDI inflows on growth. Hein (1992) find no significant relationship; the coefficient of FDI is significantly positive in Balasubramanyam , (1996) while in other papers such influence is positive or negative according to the level of development of the recipient country (Borensztein 1998, and De Mello 1999).

The presence of diverging results is due to econometric issues and to sampling differences. As far as econometrics is concerned an inadequate treatment of the endogeneity problem characterizes much of the existing empirical literature on international capital flows and growth. To the extent to which factors like the available stock of infrastructures, the market size, the presence of skilled labour and so on are recognized to be fundamental determinants of foreign capital inflows to developing countries. In addition, recent contributions on the influence of foreign capital on growth is positive when the recipient country has attained a given level of development as measured by capital, income or by available stock of human capital (Borensztein (1998) and Blomstom (1992). The "development threshold hypothesis" is clearly related to the notion of absorption capacity which recipient economies can take advantage of. The potential positive externalities that are associated with the presence of foreign Multinational Corporation (MNCs) can represent "technological enclaves in the host country, characterized by significant productivity and plant size differentials and limited productivity spillovers (De Mello and Luiz 1997 and Brewer (1991).

Other factors that may discriminate between positive and negative experiences of FDI include trade policy regime followed by host countries. The impact of FDI flows is significantly positive in economies which pursue an "Export promotion (EP) strategy and insignificant in countries which are characterized by an Import Substitution (IS) policy (Balasubramanyam, (1996) and Bhagwati (1973). In essence, both differences in development level and trade policy strategy may theoretically help to explain how the influence of foreign direct investment (FDI) on host country may vary.

In Nigeria, the ability to sustain growth and meet its external obligations depends on adequate inflow of foreign investment resources, given low level of per capita real income, high average and marginal consumption propensities, low savings and restricted new productive capital formation. It is discovered that there exists a gap between the domestically available supply of savings, foreign exchange, government revenue and skills, and planned level of these resources necessary to achieve growth targets (Todaro 1977). From the claims above, the contribution of foreign direct investment (FDI) to Nigeria remained doubtful, hence, this paper attempt to fill this vacuum.

The main objective of the paper is to examine the relationship between the flow of foreign direct investment (FDI) and economic growth in Nigeria. Other objectives includes to ascertain the viability of FDI for promoting growth in Nigeria and to examine the factors that determine locational choice of foreign direct investment in Nigeria. The rest of the paper is divided into 4 sections: section II deals with the review of literature. Section III discusses methodology and sources of data. Section IV presents results and discussion while Section $\mathrm{V}$ contains the conclusion and recommendation.

\subsection{Review of Theoretical Literature}

Jhingan (2002), defines economic growth "as the process whereby the real per capita income for a country increases over a long period of time". He states that economic growth is measured by increase in the amount of goods and services in each successive time period. Thus, growth occurs when an economy's productive capacity increases which in turn is used to produce more goods and services. It is in view of this that foreign direct investment (FDI) 
Foreign direct investment (FDI) is therefore defined "as an increase in the book value of the networth of investment in one country held by investors of another country where the investments are under the managerial control of the investor" (Graham, 1995). To buttress the definition above, Todaro and Smith (2003) noted that most FDI are infact subsidiaries of Multinational Corporations (MNCs) such that the investors are the parent organizations of firms. Thus, foreign direct investment flows represent the expansion of the international activities of Multinational Corporations.

The rationale for encouraging or attracting foreign investors to invest in developing countries is to fill the domestic capital formation gap to speed up economic growth which requires certain minimum level of foreign capital (Mieir 1964. Brewer 1991; and Digiovianni, 2005). Inspite of this encouragement, the flow of foreign direct investment (FDI) to developing countries is subject to controls exercised by the host country over the condition of entry of foreign capital, regulations of the operations of foreign capital, restrictions placed on the remittance of profits and the repatriation of capital (Meir 1964, and Morrissey and Rai 1995). Multinational Corporations (MNCs) are oligopolistic in nature hence their investment capital (FDI) gravitates towards countries and regions with highest financial returns and the greatest perceived safety to avoid the risk of capital loss. Their main objectives is profit maximization such that over $(90 \%)$ ninety per cent of global FDI goes to other industrial countries and the fastest growing developing countries while they are largely unconcerned with issues such as poverty, inequality and unemployment alleviation (Todaro and Smith 2003).

According to Carkovic and Levine (2003); Miwie (1964), Todaro and Smith (2003), FDI now accounts for over sixty percent $(60 \%)$ of private capital flows. The flow of foreign direct investment (FDI) from organization for Economic Co-operation and Developed Countries (OECD) has been extremely rapid with an average of about $\$ 4.5$ billion in 1996, up from an average of US \$3.8 billion in 1991-1995 (World Bank 1997). Africa received about 5\% of total FDI flows and FDI capital goes mainly into mineral extractions that is the petroleum industry, manufacturing and mining, with Angola, Egypt-Morocco and Gabon attracting the most (World Bank 1996). While the explosion of FDI flows is unmistakable, the growth effect remains unclear (Carkovic and Levine 2002).

The flow of foreign direct investment (FDI) into Nigeria from 1976-2006 shows that nominal FDI fluctuated from 212.5 million in 1976 to N184 million in 1979, to -N404.1 million in 1980, to N434.1 million in 1985, to N4686 million in 1990, to N75940.6 million in 1995 , N115995.7 in 2000, to N132, 433.65 in 2001 and to N573, 835.0 million in 2006. The flow of FDI in real terms also decline ranging from N830.2 million in 2000, to N4164.05 in 2005 and to N7119.89 million in 2006. In addition the analysis below shows that FDI forms only a small percentage of the nation's Gross Domestic Product (GDP). It was $0.78 \%$ in 1976 , 0.79 in $1980,1.80 \%$ in $1990,2.33 \%$ in $2000,2.79 \%$ in 2005 and $3.39 \%$ in 2006 . The increase in the 1990s was due to abandonment of restrictive measures which the indigenization decree brought against the flow of FDI and the move towards trade liberalization that favours more foreign participation in the economy. This is presented in the form of a table and trend in the appendix. (CBN Statistical Bulletin, 2001 \& 2006. Anyanwu, 1998).

In terms of the contribution of FDI to a national economy, two schools of thought emerged; the pro-foreign investment advocate. This group believes that FDI is beneficial to host countries and the world through the transmission of technology, ideas, designs, taste and better management. (Anyanwu 1998, Oloyede and Obamuyi 2000). The benefits from FDI also include filling saving resources gap, foreign exchange gap and balance of payment.

On the other hand, the anti-foreign investment approach associate themselves with the cost of FDI to host countries and assert that FDI damages host countries' economies by suppressing domestic entrepreneurship, introduction of unsuitable products and technology, subjecting 
host countries to exploitation and stimulating class conflict leading to negative contribution (Anyanwu 1998, Oloyede and Obamuyi 2000).

In reconciling the pros and cons of the role of MNCs who provide foreign direct investment (FDI) capital Todaro (1985) and Todaro and Smith (2003) asserts that while the above list provides a range or conflicting arguments, the real debate ultimately centers on different ideological and value judgments about the nature and meaning of economic growth and development and the principal sources from which it springs. However, the only valid conclusion is that foreign private investment may be an important stimulus to economic growth and social development as long as the interest of MNCs and host countries government coincide and that MNCs who provide FDI capital adopt a long-run perspective by adapting their technologies of production to the resources of developing nations.

\subsection{Review of Empirical Literature}

De Mello (1997) surveys the developments in the literature on impact of foreign direct investment (FDI) on growth in developing countries. He asserts that FDI is thought of as a composite bundle of capital stocks, know-how, and technology, and that its impact on growth is manifold and vary a great deal between technologically advanced and developing countries. He concluded that the ultimate impact of FDI on growth in recipient economy depends on the scope of efficiency spillovers to domestic firms.

Lahiri and Ono (1998) in their investigation on foreign direct investment (FDI), local content requirement and profit taxation in developing countries posited that host countries must strike a balance between costs and benefits of FDI in formulating appropriate policies. The efficiency level of domestic firms must play a role and that a host country should make use of non-tax instruments such as specification on local content of inputs to enhance benefits from FDI.

In Nigeria, significant scholarly effort has gone into the study of the role of foreign direct investment (FDI) in the Nigerian economy. Such studies include Langley (1968) who posited that FDI has both benefits and costs or repercussions in the context of Nigeria's economic growth and development. He said while FDI could engineer or accelerate gross domestic product growth (GDP) via the infusion of new techniques and managerial efficiency, Langely warns that it could also worsen the balance of payments position (Akinlo, 2004).

Oseghale and Amenkhienan (1987) examined the relationship between oil export, foreign borrowing and direct foreign investment in Nigeria on one hand and economic growth on the other hand, and the impact of these on sectoral performance between 1960 and 1984. They concluded that foreign borrowing and FDI impacted negatively on over-all GDP but positively on three principal sectors (manufacturing, transport, communication and finance and insurance).

Chete (1998) and Anyanwu (1998) separately examined the determinants of FDI in Nigeria using error correction model. Chete conclucded that the growth of the economy proxied by GDP growth rate exerts positive effect on FDI but became significant only at the third lag. While Anyanwu identified the size of the domestic market, openness of the economy and exchange rate as the core determinants of FDI flows into Nigeria. He concluded that there is a positive relationship between the growth of the Nigerian economy and foreign direct investment.

However, the criteria for judging the success of FDI by host governemnts have changed over the years and these have led to a less confrontational and a more cooperative stance between host countries and foreign investors. More particularly emphasis in evaluating inbound Multinational Corporations (MNCs) over the past three decades has switched from the direct contribution of foreign affiliates to economic growth and development to their wider impact on the upgrading of the competitiveness of host countries's indigenous capabilities and the promotion of their dynamic comparative advantage (Anyanwu, 1998; World Bank, 2003). 


\section{$3 \quad$ Methodology}

\subsection{Model Specification}

The model used in this research work is adopted from the work of Balasubramanyam (1996) and adjusted by including variables such as inflation, foreign debt, exchange rate and a political dummy. The model took a lead from Solow's Production function framework, which has been used extensively to analyze the determinants of growth in developing countries.

The testing of the hypotheses that involves the estimation of a function, which relates growth of aggregate output to growth of factor inputs, and to a variable representing growth of total factor productivity. The equation estimated is derived from the following basic neoclassical growth equation, which can be extended to any number of inputs (Chenery and Strout, 1966).

$$
Q^{g}=A^{g}+b_{1} K^{g}+b_{2} L^{g}
$$

Where

$\mathrm{Q}^{\mathrm{g}}, \mathrm{A}^{\mathrm{g}}, \mathrm{K}^{\mathrm{g}}$ and $\mathrm{L}^{\mathrm{g}}$ are the rate of aggregate output, total factor productivity, capital and labour respectively. While $b_{1}$ and $b_{2}$ are the elasticities of output with respect to the inputs.

The empirical literature on input - output relationship in developing countries suggests that the production approach is a useful reference for analysing such relationship. The general form of the equation is written as:

$$
Q^{g}=\alpha_{0}+\alpha_{1}\left(\frac{I}{Q_{t-1}}\right)+\alpha_{2} L^{g}+\alpha_{3} Z^{g}
$$

Where

$\mathrm{Q}^{\mathrm{g}}=$ Growth rate of real aggregate output

$\mathrm{I}=$ Domestic Investment

$\mathrm{Q}_{\mathrm{t}-1}=$ GDP in Previous Period (Lagged GDP)

$\mathrm{L}^{\mathrm{g}}=$ Growth rate of Labour

$\mathrm{Z}^{\mathrm{g}}=$ Growth rate of other Variables influencing factor productivity

$\mathrm{A}_{\mathrm{o}}=$ constant term assumed to represent the growth of Productivity.

$\alpha_{0}, \alpha_{1}$ and $\alpha_{3}=$ Parameters

In most empirical studies, for instance Tyler, (1981), Ram, (1985) and Balassa (1988), the variable $Z^{\mathrm{g}}$ refers to the growth of exports, inflation and agricultural growth rates as determinants of productivity. In this paper, foreign direct investment (FDI), external debts outstanding are included to capture external influence while exchange rate and political influence and the power of Nigerian Naira with reference to other foreign currencies. The augmented production function becomes

$G D P=\alpha_{o}+\alpha_{1} I N V^{g}+\alpha_{2} E X P^{g}+\alpha_{3} F D I^{g}+\alpha_{4} I N F+U_{1 t}$

However, Chete (1998) view the variable representing external influence FDI as also depending on the real growth of gross domestic product (GDP) such that a simultaneous counterpart model to equation (3) can be written as:

$\mathrm{FDI}=\mathrm{b}_{0}+\mathrm{b}_{1} \mathrm{GDP}^{\mathrm{g}}+\mathrm{b}_{2} \mathrm{EXR}+\mathrm{b}_{3} \mathrm{EXD}+\mathrm{b}_{4} \mathrm{POD}+\mathrm{U}_{2 \mathrm{t}}$

Where

GDP $=$ Growth rate of GDP 
$\mathrm{INV}^{\mathrm{s}}=$ Domestic Investment growth rate (Proxy for Domestic Capital Stock

$\mathrm{EXP}^{\mathrm{g}}=$ Exports Growth Rate

$\mathrm{FDI}^{\mathrm{g}}=$ Foreign Direct Investment growth rate

$\mathrm{INF}^{\mathrm{g}}=$ Inflation rate

$\mathrm{EXR}=$ Exchange rate

$\mathrm{EXD}^{\mathrm{g}}=$ External debt growth rate

POD - Political dummy variable (1 for democratic rule, 0 for military rule).

The a priori expectation patterns of the behaviours of the independent variables in terms of their parameters to be estimated are:

$\alpha_{1}>_{0} . \quad \alpha_{2}>_{0,} \alpha_{3}>_{0}$ and $\alpha_{4}<0$

$b_{1}>_{0} . \quad b_{2}<{ }_{0}, b_{3}>_{0}$ and $b_{4}<0$

\subsection{Estimation Technique and Sources of Data}

Equation 3 and 4 will be estimated by two-stage least squares (2SLS) method of simultaneous equation to follow new growth theory where investment is also endogenized. Time series data for the period 1976-2006 are used to analyze the model on the impact of foreign direct investment (FDI) in Nigeria. Finally, the data used were obtained from Central Bank of Nigeria (CBN) Statistical Bulletin and Financial review for the various years.

\section{Results and Discussion}

This section present the results of the two-staged least squares for the model as specified in equation 3 and 4 . Equation 4 was used as instruments for equation 3. Similarly equation 3 was used as instruments for equation 4 to capture other objectives of the paper most especially the determinants of foreign direct investment. The results are presented in tables 4.1 and 4.2 as estimated through 3.1 E-view computer packages.

\subsection{Table 1: Two-Stage Least Squares}

\section{LOG (GDP)}

Method: Two-Stage Least Squares

Sample: 1976-2006

White Heteroscedasticity - Consistent Standard Error and Covariance

Instrument List: Log (FDI) Log (EXR) Log (INF) Log (GDP) POD Log (INV) Log (EXD)

\begin{tabular}{|c|c|c|c|}
\hline Variable & Coefficient & Std Error & t-Statistic \\
\hline $\mathrm{C}$ & 11.48757 & 0.412761 & 27.83104 \\
\hline $\log (F D I)$ & -0.022700 & 0.949494 & -0.561830 \\
\hline Log (INF) & 0.044911 & 0.031290 & 1.435322 \\
\hline $\log (\mathrm{EXP})$ & 0.053011 & 0.053966 & 0.982300 \\
\hline $\log ($ INV) & -0.000563 & 0.039245 & -0.014357 \\
\hline $\log ($ EXR $)$ & 0.115738 & 0.053128 & 2.178486 \\
\hline $\log (E X D)$ & -0.097545 & 0.012152 & -6.027181 \\
\hline POD & 0.073585 & 0.044046 & 1.670657 \\
\hline $\mathrm{R}^{2}$ & 0.771914 & \multicolumn{2}{|c|}{ Mean dependent var 11051235} \\
\hline Adjusted $\mathrm{R}^{2}$ & 0.69934 & S.D. dependent & 0.211045 \\
\hline S.E. of regression & 0.115721 & Sum Squared resid & 0.294609 \\
\hline F-Statistic & 10.63641 & Durbin-Watson Stat. & .721890 \\
\hline
\end{tabular}

Source: Author's Computation 
As a kind of pre-whitering process, growth rates of data were used. The result of the regression analyses as presented in table 4.1 above shows that the coefficient of determination $\mathrm{R}^{2}$ shows that the explanatory variables explained a total variation of $77 \%$ (per cent) in the dependent variable (GDP). The result is therefore of good fit.

On a prior ground, domestic investment, and exports have their expected positive signs which indicates that there is direct relaionships between them and economic growth (GDP) in Nigeria. That is, if domestic investment and exports increase, Gross Domestic Product (GDP) will also increase (ceteris Paribus). However, investment proved significant while exports proved insignificant as reflected by their t-statistic outcome on the table. It is observed that FDI has a negative sign. This sign indicates an inverse relationship between FDI and GDP. This implies that FDI has a negative impact on (GDP) in Nigeria. An indication that Nigeria should be cautions in implementing or attracting FDI flows into Nigeria. However, this sign could be as a result of the insufficient human capital development which stands as the link between FDI insignificantly affects growth. Inflation on the other hand came up with a negative sign showing that a decrease in the rate of inflation will improve economic growth in Nigeria and its t-statistic of -3.205507 shows that it significantly influence growth at $5 \%$ (percent) level of significance.

Furthermore, exchange rate (EXR) has a positive relationship with economic growth (GDP) implying that a devaluation of the Naira will improve economic growth (GDP) in Nigeria. The variable also proved significant at 5\% level of significance as indicated by its t-statistic value of 2.178486. External debt (EXD) came up with a negative sign showing an inverse or negative relationship with growth meaning that if more debts are incurred without embarking on capital or productive goods, it will adversely affect growth in Nigeria. The t-statistic value -1.704660 shows that the variable external debt is significant at $10 \%$ level of significance. Political dummy (POD) also show a positive relationship with growth and significantly affect growth at $10 \%$ (percent) level of significance as indicated by is t-statistic value of 1.670657. This outcome is an improvement over Chete (1998) and Anyanwu (1998). This shows that with more conducive democratic dispensation, economic growth will improve in Nigeria.

The F-statistic shows that the model is useful in determining whether any relationship exists between economic growth (GDP) and foreign direct investment (FDI) in Nigeria. The F-statistic also show that the coefficient are jointly statistically significant at $1 \%$ (percent) level of significance as indicated with the t-statistic value of 10.636441. The Durbin Watson (DW) which is 1.721890 shows that there is no positive serial correlation in the model.

In realizing the objective of the viability of foreign direct investment (FDI), FDI has a negative relationship with economic growth (GDP). The empirical result as indicated on table 4.1 suggests that FDI may not be viable to the government and private households in Nigeria when overall economic growth is considered. This could be due to the low level of development of human capital in Nigeria which could have created the necessary linkages between FDI and economic growth through imitation and training in order to actualize the spillover effect from new technologies. To realize the objective of the determinants of the locational choice of foreign direct investment (FDI), we present tables 4.2 in which FDI was used as a dependent variable and other factors used as determinants.

\subsection{Table 2: Determinants of Locational Choice of FDI}

Dependent Variable: LOG (FDI)

Method: Two Stage Least Squares

Sample: 1976-2006

White Hetgeroscedasticity-Consistgent Standard Errors \& Covariance Instrument List: Log (GDP) Log (INV) Log (EXP) Log (INF) Log (EXR) Log (EXD) POD. 
Vol.4, No.2, 2013

\begin{tabular}{|c|c|c|c|}
\hline Variable & Coefficient & Std Error & t-Statistic \\
\hline $\mathbf{C}$ & 3.930091 & 10.31653 & 0.380951 \\
\hline $\log ($ GDP) & -0.503476 & 0.855298 & -0.588655 \\
\hline $\log ($ INV) & 0.187899 & 0.362582 & 0.518224 \\
\hline $\log (\mathrm{EXP})$ & 0.539658 & 0.383881 & 1.405797 \\
\hline $\log (\mathrm{INF})$ & 0.128325 & 0.126420 & 1.015071 \\
\hline $\log (\mathrm{EXR})$ & 0.514371 & 0.314934 & 1.633265 \\
\hline $\log (E X D)$ & 0.101502 & 0.151061 & 0.671924 \\
\hline POD & -0.342396 & 0.234116 & -1.462506 \\
\hline $\begin{array}{c}\mathrm{R}^{2} \\
0.962809\end{array}$ & & \multicolumn{2}{|c|}{ Mean dependent var 9.078812} \\
\hline Adjusted $\mathrm{R}^{2}$ & 0.544987 & S.D. dependent & 2.825962 \\
\hline S.E. of regression & 108.2507 & Sum Squared res & 0.534241 \\
\hline F - Statistic & & Durbin-Watson & 026787 \\
\hline
\end{tabular}

Source: Author's Computation

Table 4.2 above shows that the coefficient of determination $\mathrm{R}^{2}$ is 0.971786 which means that the explanatory variables explained a total variation of $97 \%$ (percent) of the dependent variable (FDI). On a priori ground all the variables have their expected signs except Log (GDP) which has a negative sign. This also confirms the same inverse relationship between GDP and FDI a explained earlier on. This could be as a result of inadequacy of FDI fund injected into the Nigerian economy or due to capital flight through repatriation of profits, over invoicing or transfer pricing from Nigeria. Locational factors of FDI therefore include exports, (EXP) exchange rate (EXR) and POD as shown by their coefficients 0.539658 , $0.514371,-0.342396$ and their t-statistic of $1.405797,(10 \%), 1.633265(10 \%)$ and -1.462506 $(10 \%)$ respectively. While exports and exchange rates are positive, POD came up with a negative sign. This sign corresponds with Ibrahim and Omoniyi (2009). All other factors proved positive but insignificant as a determinant of locational factors of FDI in Nigeria. Finally, the DW shows the absence of autocorrelation in the model with the value 2.026787.

\section{Conclusion}

In conclusion, the empirical results show that there is negative relationship between economic growth (GDP) and FDI contrary to the belief of authorities in charge of growth and development. This negative relationship could be as a result of insufficient FDI fund invested into the Nigerian economy which has not been able to exert enough impact to make it positive or growth enhancing. Despite the negative relationship between GDP and FDI, this does mean that FDI is not viable to the Nigerian government and private households because spillovers are different in nature. It was also discovered that exports, exchange rate and political factor form the major locational factors of FDI in Nigeria.

\subsection{Recommendation}

Based on the conclusion above, the following recommendations are made:

- $\quad$ Nigeria should encourage improved domestic investment to accelerate growth rather than relying on FDI as a prime mover of the economy.

- Nigeria should develop a code of conduct on multinational corporation to curb their restrictive business practice, limit their repatriation of profits from Nigeria and ensure that significant part of their profits are re-invested into the Nigerian economy.

- The government should re-visit the issue of local content requirement.

- Nigeria should pursue guided trade liberalization

- Finally, Nigeria should ensure a stable government by guaranteeing the sustainability of democratic rule devoid of unwarranted changes. 


\section{References}

Akinlo, A.E. (2004) "Foreign Direct Investment and Growth in Nigeria", Journal of Poicy Modelling 26 pp: 627-639.

Anyanwu, J.C. (1998): “An Econometric Investigation of the Determinant of FDI", Nigerian Journal of Economic and Social Studies, Selected Paper for 1998 Annual Conference, pp. 218-240.

Balasubramanyam, V.N (1996) "Foreign Direct Investment and Growth in EP and IS countries", the Economic Journal of Development Studies Vol. 106, pp. 92-106.

Balassa, B. (1988): Exports and Economic Growth Further Evidence". Journal of Developing Economics, Vol. 5 pp: 181-189.

Bhagwati, J.N. (1973): "The Theory of Immiserizing Growth: Further Applications", in M.B. Conolly and A.K. Swoboda, eds, International Trade and Money, University of Toronto Press, pp. 45-54.

Blomstrom, M. (1992): "What Explains Developing Country growth", NBER Working Paper No 4132.

Borensztein, E. (1998): "How Does Foreign Direct Invwestment Affect Economic growth?" Journal of International economics Vol. 45, pp. 115-135.

Bornchier, V. (1978): “Cross-national Evidence of the Effects of Foreign Investment and Aid on Economic growth and Inequality: a Survey of Findings and a Reanalysis, American Journal of Sociology, Vol. 84, No. 3, pp. 651-683.

Brewer, T.L. (1991): "Foreign Direct Investment in Developing Countries: Pattern, Policies and Prospects", World Bank Policy Research Working Paper No. 712.

Carkovic, M. and Levine, R. (2002): "Does Foreign Direct Investment Accelerate Economic Growth?”, Univderisty of Minnesota, MN 55455; Rlevine @ Scom, Umn. Edu. Minneapolis.

CBN Statistical Bulletin 2001 and 2006.

Chenery, H.B. and Strout, A.M. (1966): "Foreign Assistance and Economic Developments", American Review 56.

Chete, L.N. (1998): "Determinants of Foreign Direct Investment in Nigeria", The Nigerian Journal of Economics and Social Stdies, Vol. 1. No.1

De Mello, L.R. and Luiz R. (1997)» FDI in Developing Countries and Growth », The Journal of Development Studies Vol. 34 No. 1, pp 1-34.

De Mello, L.R. Jr. (1999): "Direct Foreign Investment - Led Growth: Evidence from Time Series Panel Data", Oxford Economic Paper Vol. 51, pp. 133-151.

Digiovanni, J. (2005): "What Drives Capital Flows? The Case of Cross-border MPA. Activity and Financial Deepening". Journal of International Economics, pp. 65.

Dutt, A.K. (1996): "Direct Foreign Investment and North-South Trade: Unoven Development or Convergent Growth?" in Development Economics and Policy, eds. J. Chen and D. Sapsford, Macmillan, London.

Dutt, A.K. (1997): “The Pattern of Direct Foreign Investment and Economic Growth", World Development, Vol. 25 No. 11, pp. 1925-1936. 
Feenstra, R.C. and Markusen, J.P. (1994): "Accounting for Growth with New Inputs", International Economic Review, 35 pp. 429-447.

Findlay, R. (1978): "Relative Backwardness, Direct Foreign Investment and the Transfer of Technology: a Simple Dynamic Model”, Quarterly Journal of Economics Vol. 92, pp. 1-16.

Graham, E.M. (1995): "Foreign Direct Investment in the World Economy, IMF World Economic and Financial Survey. Pp: 120-135.

Ibrahim, W and Omoniyi, B.B. (2009): "Determinants of FDI, Political Factor Effect Re-visited”, The Journal of Social Science.

Jhingan, M.L. (2002): “Macroeconomics Theory” 10 th Edition, Vrinda Delhi pp. 603.

Lahiri, S. and Ono, Y. (199): "Foreign Direct Investments Local Content Requirement and Profit Taxation", The Economic Journal, Vol. 10, pp 444-457.

Langley, K.M. (1968): “The External Resource Factor in Nigeria's Economic Development”, NIES Vol. 10 No. 2.

Martin, P. and Ottaviano, G.I.P (1999) "Growing Location in a Model of Endogenous Growth: European Economic Review.

Mieir, G.M. (1964) Leading Issues in Economic Development, Oxford University Press, London, pp. $14 \mathrm{a}-168$.

Oloyede, J.A. ND Obamuyi, T.M. (2000): "The Impact of Direct Investment on the Nigerian Economy", Nigerian Journal of Banking and Financial Issues, Vol. 3. No. 1, pp. 1-21.

Ibrahim, W. and Omoniyi, B.B. (2009): Determinants of Foreign Direct Investment in Nigeria: Political Factor Effect revisited. Journal of Economics and Social Studies, University of Ado-Ekiti, Nigeria. Vol. 6 pp.55-67

Oseghale, B.D. and Amenkhienan, F.E. (1987): "Foreign Debt, Oil Exports and Direct Foreign Investment and Economic Performance" Nigerian Journal of Economic Studies Vol. . No.3.

Ram, R. (1985): Export and Economic Growth: Some Additional Evidence: Economic Development and Cultural Change.

Todaro, M.P. (1985) "Economic Development in the Third World" $3^{\text {rd }}$ Edition, Longman Publisher.

Todaro, M.P. and Smith, S.C. (2003): Economic Development, $8^{\text {th }}$ Edition, Pearson Education Asia.

Tyler, W.G. (1981): Growth and Exports Expansion in Developing Countries" Journal of Development Economics 9.

World Bank (1996): World Debt Table External Finance for Developing Countries Vol. 1, Washington D.C.

World Bank (2003): "Financial Flows and the Developing Countries", A World Bank Business Quarterly, Quarter 3. 


\section{Appendix}

FLOW OF FDI IN NIGERIA 1976 - 2006

\begin{tabular}{|c|c|c|c|}
\hline & Nominal (NM) & Real FDI (NM) & FDI/GDP (\%) \\
\hline 1976 & 212.5 & 830.08 & 0.78 \\
\hline 1977 & 245.5 & 829.39 & 0.75 \\
\hline 1978 & 134.4 & 389.57 & 0.37 \\
\hline 1979 & 184.3 & 478.70 & 0.43 \\
\hline 1980 & -404.1 & -955.32 & -0.79 \\
\hline 1981 & 334.7 & 653.71 & 0.66 \\
\hline 1982 & 290.0 & 526.32 & 0.56 \\
\hline 1983 & 264.3 & 536.52 & 0.46 \\
\hline 1984 & 360.4 & 380.17 & 0.57 \\
\hline 1985 & 434.1 & 434.10 & 0.60 \\
\hline 1986 & 735.8 & 698.10 & 1.01 \\
\hline 1987 & $2,553.8$ & $2,199.66$ & 2.25 \\
\hline 1988 & $1,718.2$ & 948.23 & 1.18 \\
\hline 1989 & $13,877.4$ & $5,088.89$ & 6.17 \\
\hline 1990 & $4,684.0$ & $1,597.54$ & 1.80 \\
\hline 1991 & $6,916.1$ & $2,090.09$ & 2.13 \\
\hline 1992 & $14,463.1$ & $3,023.22$ & 2.63 \\
\hline 1993 & $29,660.3$ & $3,944.71$ & 4.25 \\
\hline 1994 & $22,229.2$ & $1,882.71$ & 2.43 \\
\hline 1995 & $75,940.6$ & $3,721.85$ & 3.84 \\
\hline 1996 & $111,295.0$ & $4,218.76$ & 3.94 \\
\hline 1997 & $110,452.7$ & $3,857.53$ & 3.76 \\
\hline 1998 & $80,750.4$ & $2,564.16$ & 2.80 \\
\hline 1999 & $92,792.5$ & $2,763.66$ & 2.77 \\
\hline 2000 & $115,952.2$ & $3,229.42$ & 2.33 \\
\hline 2001 & $132,433.7$ & $3,192.95$ & 2.35 \\
\hline 2002 & $225,036.5$ & $4,595.40$ & 3.81 \\
\hline 2003 & $258,388.6$ & $4,703.70$ & 2.55 \\
\hline 2004 & $248,224.6$ & $3,608.41$ & 2.13 \\
\hline 2005 & $302,753.4$ & $4,164.05$ & 2.79 \\
\hline 2006 & 573835.0 & $7,119.89$ & 3.93 \\
\hline
\end{tabular}

CBN Statistical Bulletin \& Author's Computation

*Awe, A. A. joined the service of Ekiti State University in the year 1993 as an Assistant Lecturer. He is now an Associate Professor of Economics and serving as Head of Department, Department of Accounting Ekiti State University.

He was born $6^{\text {th }}$ of July, 1960 and a senior member of Nigerian Economic Society. He holds B.Sc., Economics in University of Ilorin (1986); M.Sc. Economics, University of Lagos (1992) and PhD. Economics, Federal University of Technology, Akure, Onodo State Nigeria (2004). He has been teaching Microeconomics, Macroeconomics and Econometrics in the Ekiti State University Ado-Ekiti since 1993. 
This academic article was published by The International Institute for Science, Technology and Education (IISTE). The IISTE is a pioneer in the Open Access Publishing service based in the U.S. and Europe. The aim of the institute is Accelerating Global Knowledge Sharing.

More information about the publisher can be found in the IISTE's homepage: http://www.iiste.org

\section{CALL FOR PAPERS}

The IISTE is currently hosting more than 30 peer-reviewed academic journals and collaborating with academic institutions around the world. There's no deadline for submission. Prospective authors of IISTE journals can find the submission instruction on the following page: http://www.iiste.org/Journals/

The IISTE editorial team promises to the review and publish all the qualified submissions in a fast manner. All the journals articles are available online to the readers all over the world without financial, legal, or technical barriers other than those inseparable from gaining access to the internet itself. Printed version of the journals is also available upon request of readers and authors.

\section{IISTE Knowledge Sharing Partners}

EBSCO, Index Copernicus, Ulrich's Periodicals Directory, JournalTOCS, PKP Open Archives Harvester, Bielefeld Academic Search Engine, Elektronische Zeitschriftenbibliothek EZB, Open J-Gate, OCLC WorldCat, Universe Digtial Library, NewJour, Google Scholar

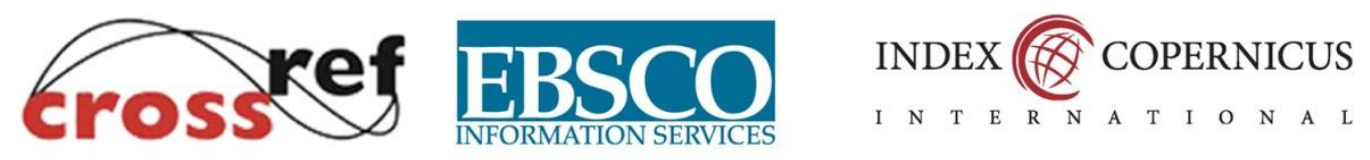

(O) ULRICHSWEB"

JournalTOCs

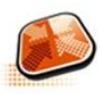

PKP | PUBLIC KNOWLEDGE PROJECT
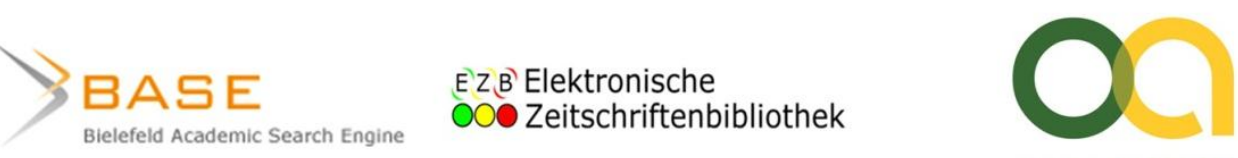

open access
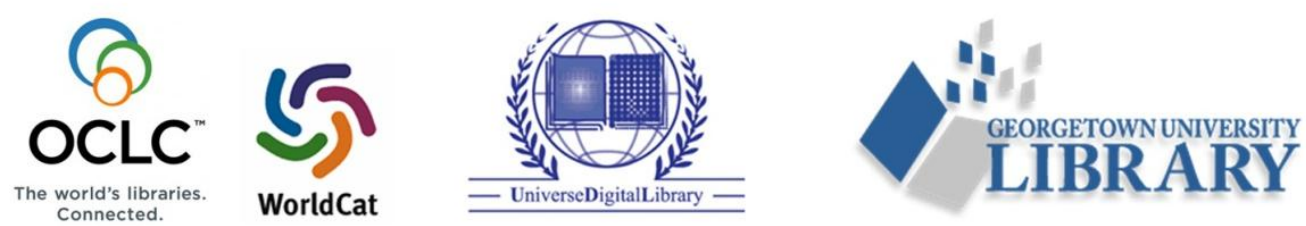